\title{
IMPLEMENTASI ALGORITMA FUZZY LOGIC PADA ROBOT ARM DENGAN MEMANFAATKAN ACCELEROMETER SMARTPHONE ANDROID
}

\author{
Nanda Tommy Wirawan ${ }^{1}$ \\ Retno Devita ${ }^{2}$
}

\begin{abstract}
Now the development of smart phone technology has evolved rapid, especially Smartphone Android. Where multiple sensors embedded in a mobile phone, primarily an accelerometer sensor support be used of smartphone phone. Accelerometer is used to measure the acceleration reviews Angle $X, Y$ and $Z$ smartphone. So that the sensor is used to review the Movement Robot Arm matching is done with corner acceleration motion $X, Y$ and $Z$ smartphone Method on the system is backed with Fuzzy Logic the which serves to Determine the movement of the robot arm that is sent to the microcontroller. Arm robot system is processed using Matlab 6.1 and using the Software Arduino, and then implanted into the microcontroller, so that the robot goes According movement.
\end{abstract}

Keywords : Android, Accelerometer, Robot Arm, Fuzzy Logic.

\section{INTISARI}

Perkembangan teknologi ponsel pintar sekarang sudah berkembang pesat, terutama smartphone Android. Dimana di dalam ponsel tersebut ditanamkan beberapa sensor, terutama sensor accelerometer yang mana mendukung kinerja ponsel smartphone tersebut. Accelerometer ini digunakan untuk mengukur percepatan sudut $\mathrm{X}, \mathrm{Y}$ dan $\mathrm{Z}$ pada smartphone. Sehingga sensor ini dimanfaatkan untuk robot Arm dalam melakukan pergerakan yang sesuai dengan pergerakan percepatan sudut $\mathrm{X}, \mathrm{Y}$ dan $\mathrm{Z}$ pada smartphone. Metode pada sistem ini didukung dengan Fuzzy Logic yang berfungsi untuk menentukan pergerakan robot Arm yang dikirimkan ke mikrokontroller. Sistem robot Arm ini diolah menggunakan Matlab 6.1 dan menggunakan Software Arduino, lalu ditanamkan ke dalam mikrokontroller, sehingga robot berjalan sesuai pergerakannya.

Kata Kunci : Android, Accelerometer, Robot Arm, Fuzzy Logic.

\footnotetext{
1,2 Universitas Putra Indonesia "YPTK" Padang
} 


\section{PENDAHULUAN}

Perkembangan dunia industri pada saat ini semakin terus berkembang dan sudah menjadi satu bagian penting dari dunia secara keseluruhan. Perkembangan dunia industri ini sudah banyak memberikan kemudahan dan keuntungan tersendiri kepada perusahaan dalam pengerjaannya. Sebagai contoh adalah proses pemindahan dan pengelompokkan barang yang dilakukan secara berulang-ulang. Pada dunia industri benda yang akan dipindahkan tidak hanya satu ukuran, melainkan banyak seperti dalam proses pemindahan dan pengelompokkan kardus makanan dengan ukuran yang kecil, sedang dan besar. Jika proses pemindahan dan pengelompokkan masih menggunakan tenaga manusia (manual) maka akan banyak menghabiskan waktu dan tenaga.

Untuk menghemat proses tersebut, maka muncul ide untuk membuat ROBOT Arm yang dapat bekerja dengan memanfaatkan accelerometer android sebagai pengontrol Robot Arm dengan metode Algoritma Fuzzy Logic yang mengkatkan keakurasian robot untuk menjalankan proses produksi pada perusahaan sesuai dengan target yang diinginkan.

Dengan Ini akan sangat
memudahkan pekerja dalam
pemindahan barang dan akan
menghemat tenaga dan waktu
pengerjaannya.

\section{PENDEKATAN DAN \\ PEMECAHAN MASALAH \\ Robot}

Istilah robot pertama kali diperkenalkan dalam bahasa Inggris pada tahun 1921 oleh seorang dramawan Cekoslowakia yang bernama Karel Capek dalam dramanya yang berjudul R.U.R (Rossum's Universal Robots). Robot dalam arti mula-mula adalah "forced labour' yang berarti pekerja paksa, namun dalam pengertian modern kata robot sudah mengalami perluasan makna. Menurut The Robotics International Division of The Society of Manufacturing Engineers (RI/SME), robot dapat didefinisikan sebagai manipulator reprogrammable dan multifungsi yang dirancang untuk memindahkan material , bagian , peralatan, dan perangkat khusus melalui variabel gerakan yang diprogram untuk kinerja berbagai tugas (Deny Wiria Nugraha, 2010).

Dari pengertian di atas, terdapat tiga kata kunci yang menunjukkan ciri sebuah robot yaitu: reprogrammable (dapat diprogram kembali), multifunctional (multifungsi), dan move material, part, tools (mendefinisikan tugas manipulator). Jadi definisi robot, khususnya robot industri adalah perangkat multifungsi yang dirancang untuk memanipulator dan mentransformasikan alat atau perangkat tertentu melintasi suatu lintasan yang telah diprogramkan guna menyelesaikan tugas-tugas tertentu. Untuk dapat disebut sebagai sistem robot modern, sebuah mesin sedikitnya terdiri dari tiga hal utama yaitu:

a. Manipulator

Manipulator yaitu merupakan unit mekanik yang melakukan fungsi gerakan. Pada robot, manipulator biasanya terdiri dari bagian lengan (main frame) dan bagian pergelangan (wrist). Fungsi dari manipulator ini adalah untuk memungkinkan robot untuk mencapai suatu posisi tertentu dengan presisi.

b. Aktuator

Berfungsi sebagai
sumber tenaga untuk
menggerakkan manipulator.
Aktuator pada robot dapat
memakai sistem hidrolik,
sistem pneumatik, motor DC,


motor AC, motor stepper dan berbagai jenis penggerak lainnya.

c. Prosesor

Merupakan otak dari robot, berfungsi untuk menyimpan dan memproses setiap urutan gerakan pada robot. Biasanya bagian prosesor ini memungkinkan robot untuk melakukan berbagai jenis tugas yang diprogramkan kepadanya.

\section{Sistem Kontrol Loop Terbuka (Open Loop)}

Suatu sistem kontrol yang mempunyai karakteristik di mana nilai keluaran tidak memberikan pengaruh pada aksi kontrol disebut Sistem Kontrol Loop Terbuka (OpenLoop Control System) (Aris Triwiyatno, 2011).

Diagram kontrol loop terbuka pada sistem robot dapat dilihat pada gambar 1.

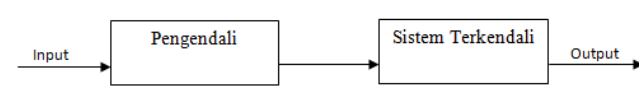

\section{Gambar 1. Sistem Kontrol Robot Loop Terbuka}

\section{Sistem Kontrol Loop Tertutup (Close Loop)}

Diagram kontrol loop tertutup dapat dilihat pada gambar 2 .

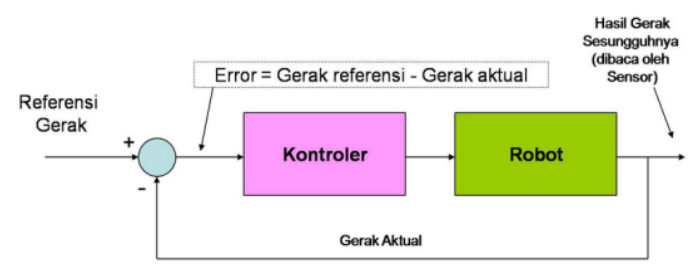

Gambar 2. Sistem Kontrol Robot
Loop Tertutup

Pada gambar di atas, jika hasil gerak aktual telah sama dengan referensi maka input kontroler akan nol. Artinya kontroler tidak lagi memberikan sinyal aktuasi kepada robot karena target akhir perintah gerak telah diperoleh. Makin kecil error terhitung, maka makin kecil pula sinyal pengemudian kontroler terhadap robot, sampai akhirnya mencapai kondisi tenang (steady state).

Referensi gerak dan gerak actual dapat berupa posisi kecepatan, akselerasi atau gabungan diantaranya. Kontrol bersifat konvergen jika dalam rentang waktu pengontrolan nilai error menuju nol, dan keadaan dikatakan stabil jika setelah konvergen kontroler mampu menjaga agar error selalu nol. Dua pengertian dasar; konvergen dan stabil, adalah sangat penting dalam kontrol loop tertutup. Stabil dan konvergen diukur dari sifat referensinya.

Posisi akhir dianggap konvergen jika makin lama gerakan makin perlahan dan akhirnya diam pada posisi seperti yang dikehendaki referensi, dan dikatakan stabil jika posisi akhir yang diam dapat dipertahankan dalam masamasa berikutnya. Jika referensinya adalah kecepatan maka disebut stabil jika pada keadaan tenang kecepatan akhirnya adalah sama dengan referensi dan kontroler mampu menjaga kesamaan ini pada masa-masa berikutnya (Aris Triwiyatno, 2011).

\section{Robot Arm}

Sebuah robot industri terdiri dari sebuah manipulator robot, power supply, dan pengontrol. Manipulator robot dapat dibagi menjadi dua bagian, masingmasing dengan fungsi yang berbeda yaitu :

a. Lengan dan Tubuh - lengan dan tubuh robot digunakan untuk memindahkan bagianbagian posisi dan atau alat dalam amplop kerja. Mereka terbentuk dari tiga sendi dihubungkan dengan link besar. 
b. Wrist - pergelangan tangan ini digunakan untuk mengarahkan bagian-bagian atau peralatan di lokasi kerja. Ini terdiri dari dua atau tiga kompak sendi. Manipulator robot dibuat dari urutan kombinasi link dan sendi. Link yang menghubungkan para anggota kaku sendi, atau kapak.

Sumbu adalah komponen bergerak dari robot yang menyebabkan gerakan relatif antara link yang berdekatan. Sendi mekanis digunakan untuk membangun manipulator terdiri dari lima jenis utama. Dua dari sendi yang linear, di mana gerakan relatif antara link yang berdekatan adalah non-rotasi, dan tiga jenis rotary, di mana gerakan relatif melibatkan rotasi antara link. Bagian lengan-dantubuh manipulator didasarkan

pada salah satu dari empat konfigurasi. Masing-masing anatomi memberikan amplop kerja yang berbeda dan cocok untuk aplikasi yang berbeda yaitu :

1. Gantry - robot ini memiliki sendi linier dan dipasang overhead. Mereka juga disebut robot Cartesian dan bujursangkar.

2. Cylindrical - Dinamakan untuk bentuk tempat kerjanya, robot anatomi silinder yang dibuat dari sendi linear yang terhubung ke basis bersama rotary.

3. Polar- Dasar bersama robot kutub memungkinkan untuk memutar dan sendi adalah kombinasi jenis putar dan linier. Ruang kerja yang diciptakan oleh konfigurasi ini bulat.

4. Joined-Arm - Ini adalah konfigurasi yang paling populer robot industri. Lengan menghubungkan dengan bersama memutar, dan link di dalamnya dihubungkan dengan sendi putar. Hal ini juga disebut robot diartikulasikan.

\section{Accelerometer}

Accelerometer modern tidak lain adalah MEMS (micro electro mechanical system) berskala kecil. Accelerometer adalah suatu alat untuk mengukur percepatan, mendeteksi dan mengukur getaran, atau untuk mengukur percepatan gravitasi (inklinasi). Pengukurannya bisa secara analog maupun digital. Accelerometer dapat digunakan untuk mengukur percepatan baik statis maupun dinamis. Accelerometer akan mengalami percepatan dalam kisaran dari $-1 \mathrm{~g}$ sampai $+1 \mathrm{~g}(9.8 \mathrm{~m} / \mathrm{s} 2)$, dan hingga kemiringan $180^{\circ}$.

Accelerometer merupakan komponen elektronik yang mengukur kemiringan dan gerak. Accelerometer juga mampu untuk membaca gerakan rotasi dan gerakan seperti berayun atau bergetar. Pada smartphone Accelerometer merupakan sensor yang bisa membaca pergerakan sehingga dapat mengubah tampilan layar dari posisi landscape ke portrait atau sebaliknya dengan cukup memiringkan badan ponsel secara otomatis (Dedy Hermanto, 2015). Dapat dilihat pada gambar 3.

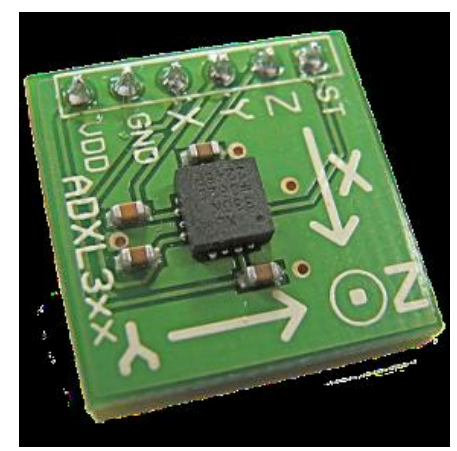

\section{Gambar 3. Sensor Accelerometer}

\section{Fuzzy Logic}

Logika Fuzzy sebagai salah satu komponen dari perangkat lunak, telah banyak diaplikasikan diberbagai bidang kehidupan. Salah satu aplikasi terpentingnya adalah membantu manusia dalam 
melakukan pengambil keputusan. Aplikasi logika Fuzzy untuk pendukung keputusan sangat diperlukan tatkala semakin banyak kondisi yang menuntut adanya keputusan yang hanya bisa dijawab dengan "ya' atau "tidak'. Hal ini muncul sebagai akibat dari adanya ketidakpastian yang menyertai data yang diterima atau informasi sebagai hasil pengolahan data. Pada dasarnya berhubungan dengan bagaimana manusia menangani ketidaktepatan (imprecise) dan informasi yang tidak pasti (uncertain). la menirukan bagaimana manusia menggunakan perkiraan pertimbangan (approximate reasoning) dalam hal berhubungan dengan ketidaktepatan (impresion), ketidakpastian (uncertainty), ketidakakurasian (inaccuracy), ketidakpersisan (inexactness), kerancuan ketidakjelasan kekualitatifan (ambiguity), (vagueness), persepsi (perception) yang dialami setiap hari dalam pengambilan keputusan (T. Sutojo et al, 2011).

Dengan menggunakan Fuzzy Logic, dalam merancang sebuah system akan lebih cepat dan efisien.

Kemudian, Fuzzy Logic juga kental berkaitan dengan sistem control, di bidang elektronika sehingga pernyataan matematiknya banyak dikembangkan dalam konteks pemrograman komputer (Endra Pitowarno, 2006).

\section{HASIL DAN PEMBAHASAN Arsitektur Robot}

Robot ini memiliki arsitektur dengan bagian-bagiannya sebagai berikut :

1. Komponen Input

Komponen input yang dipakai pada robot ini adalah Smartphone Andorid dan Bluetooth HC-05. Pada
Smartphone Android yang difungsikan adalah Accelerometer dimana berfungsi sebagai penggerak robot dan Bluetooth HC-05 berfungsi sebagai interface antara Smartphone Android dan Robot.

2. Komponen Proses

Komponen proses yang dipakai yaitu:

- Mikrokontroller Arduino Berfungsi sebagai pemroses atau otak pada robot. Mikrokontroller Arduino melakukan segala proses yang terjadi mulai dari pengolahan data yang masuk dan memberikan keluaran berupa tegangan yang nantinya keluarannya itu akan dikirim ke tiap servo. Pada mikrokontroller inilah akan dimasukkan logika fuzzy yang berfungsi untuk mengatur pergerakan robot Arm.

3. Komponen Output

Komponen output yang dipakai pada robot ini yaitu :

- Servo

Berfungsi sebagai aktuator gerak daripada robot. Servo yang digunakan adalah empat buah.

Dapat dilihat pada gambar 4 .

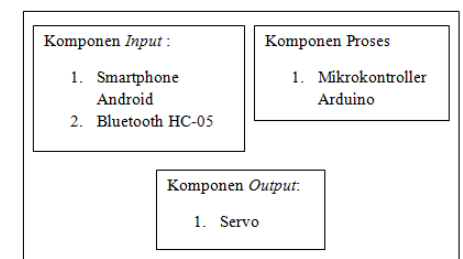

\section{Gambar 4. Arsitektur Robot}

\section{Arsitektur Sistem}

Pada sistem robot ini, robot bekerja diawali dengan mengambil nilai yang dihasilkan oleh Accelerometer. Nilai-nilai yang didapatkan akan menjadi masukan bagi mikrokontroller Arduino untuk diolah menggunakan logika Fuzzy, dan nilai-nilai yang dihasilkan dari 
proses Fuzzy tersebut dikirimkan ke Servo, sehingga Servo bergerak pada derjat tertentu dan dapat dilihat pada gambar 5 .

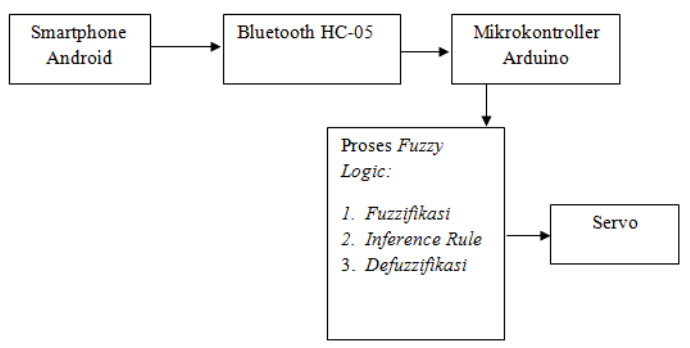

Gambar 5. Arsitektur Sistem

\section{Context Diagram}

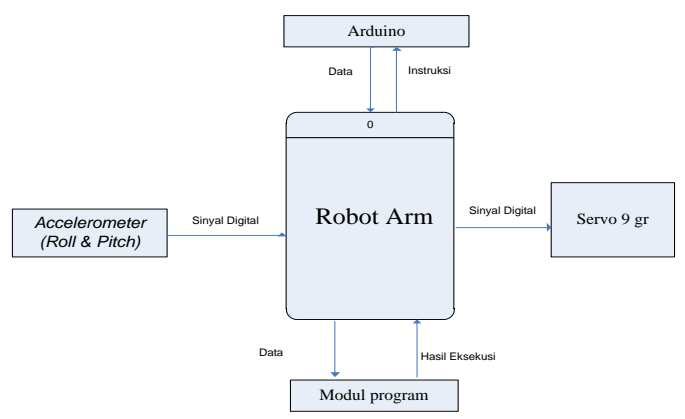

Gambar 6. Context Diagram

\section{Data Flow Diagram}

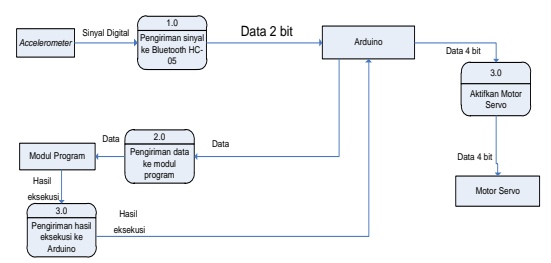

\section{Gambar 7. Data Flow Diagram}

\section{Rancangan Modul Program}

$$
\text { Modul program dirancang }
$$

memiliki struktur dengan kualitas yang baik dan mudah dimengerti, maka sebelum pembuatan listing program perlu diawali dengan penentuan logika program. Logika program pada robot ini yaitu :

Logika program tersebut pada penelitian ini digambarkan dalam bentuk flowchart dan dapat dilihat pada gambar 8.

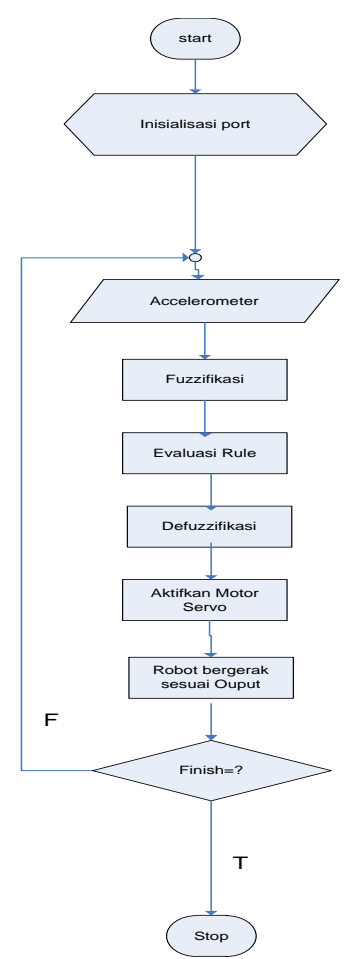

\section{Gambar 8. Flowchart}

\section{Pembuatan Mekanik Robot}

Pada tahap ini, diperlukan bahan akrilik untuk membuat mekanik robot. Robot yang dibuat berukuran $30 \mathrm{~cm} \times 9 \mathrm{~cm} \times 18 \mathrm{~cm}$.

\section{Gambar} rancangan bentuk mekanik robot ini dapat dilihat pada gambar 9 .

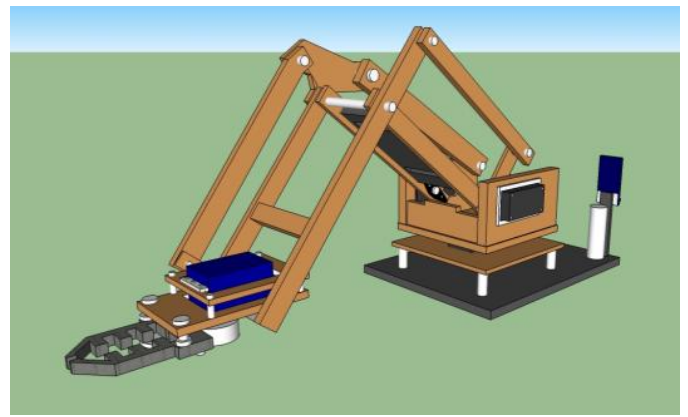

\section{Gambar 9. Rancangan Mekanik} Awal Robot

\section{Pembuatan Modul Rangkaian}

Pada pembuatan modul rangkaian ini, ada beberapa tahap yang harus dilakukan, yaitu:

1. Tahap Merancang Simulasi Rangkaian Elektronik 
Pada tahap ini, software yang dibutuhkan adalah Proteus 7 Professional. Setelah rancangan simulasi rangkaian elektronik robot, selanjutnya pengaplikasian ke sistem. Bentuk hasil rancangan simulasi rangkaian elektronik robot yang dihasilkan oleh software Proteus 7 Professional dapat dilihat pada gambar 10 .

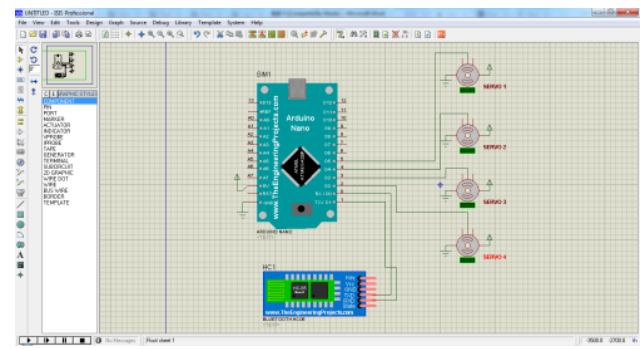

Gambar 10. Hasil Rancangan Simulasi Rangkaian Elektronik Robot

2. Tahap Penyolderan

$$
\begin{aligned}
& \text { Pada tahap ini, yang } \\
& \text { harus dikerjakan adalah } \\
& \text { menyolder komponen- } \\
& \text { komponen elektronik ke papan } \\
& \text { PCB. }
\end{aligned}
$$

3. Tahap Penggabungan

Pada tahap ini, yang dilakukan adalah penggabungan masingmasing modul rangkaian.

\section{Penyelesaian Robot}

Tahap ini adalah tahap penyelesaian pembuatan bentuk fisik robot yang sudah terpasang lengkap dengan rangkaianrangkaian elektronik robot. Bentuk fisik robot dapat dilihat pada gambar 11.

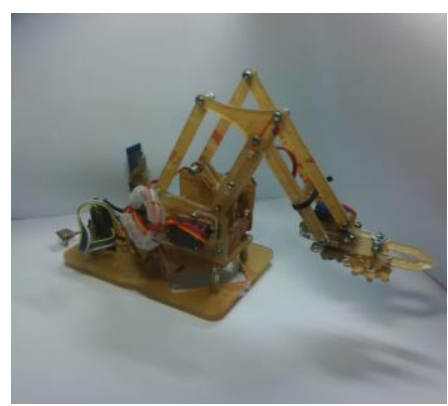

Gambar 11. Bentuk Fisik Robot

\section{Implementasi Fuzzy Logic ke Robot Arm}

Untuk mengimplementasikan metode Fuzzy Logic pada robot ini, logika yang digunakan adalah IFThen. Software yang digunakan adalah Arduino. Software ini berfungsi sebagai software untuk pemrograman robot. Bahasa pemrograman yang digunakan pada software ini adalah bahasa $\mathrm{C}++$. Langkah-langkah pemrogramannya yaitu:

a. Buka aplikasi Arduino

Bentuk tampilan Arduino dapat dilihat pada gambar 11 .

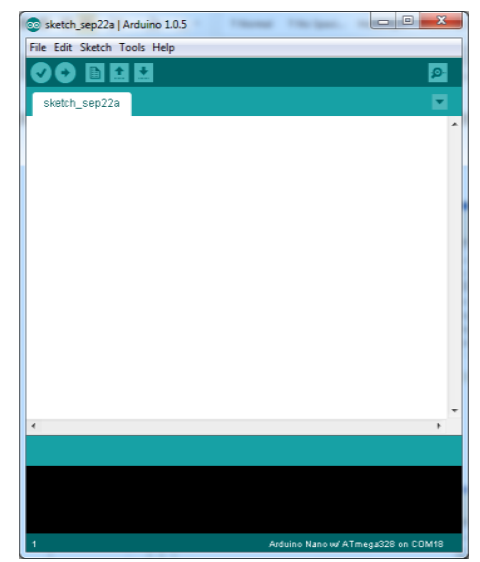

\section{Gambar 11. Tampilan Arduino}

b. Program

Tahap ini berfungsi untuk menulis program utama untuk pergerakan robot yang berdasarkan Fuzzy Logic. dapat dilihat pada gambar 12 .

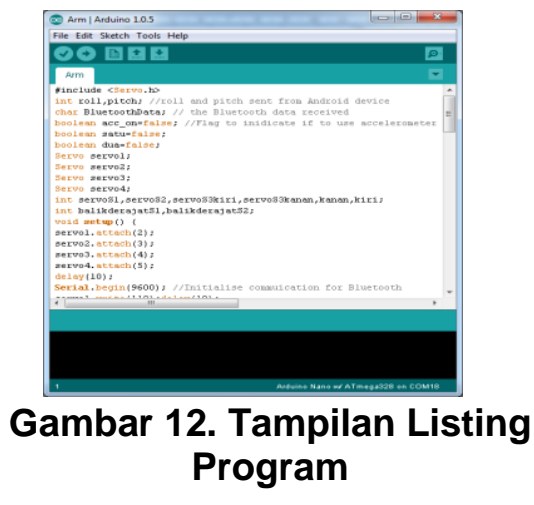


Program untuk robot mengambil rumus dari Fuzzy Logic yang dihasilkan oleh software Matlab 6.1. Contoh listing programnya yaitu:

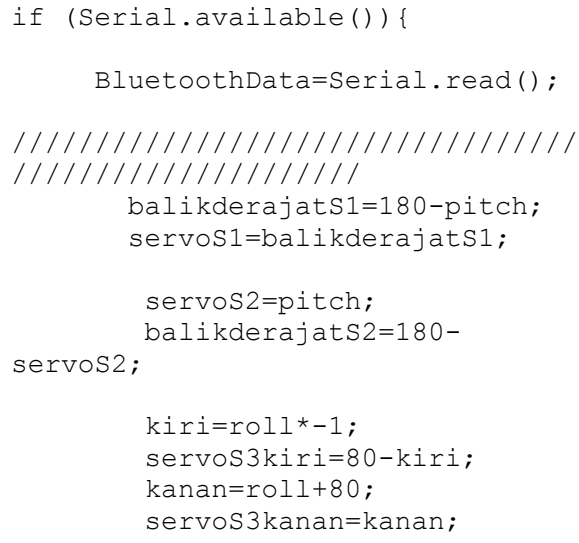

if (Serial.available()) \{

BluetoothData=Serial.read ();

$1 / 1 / 1 / 1 / 1 / 1 / 1 / 1 / 1 / 1 / 1 / 1 / 1 / 1 / 1$ //////////////////

balikderajats1=180-pitch; servos1=balikderajats1;

servos2=pitch;

balikderajats2=180-

servos2;

kiri=roll* -1 ;

servos3kiri=80-kiri;

kanan=roll +80 ;

servos3kanan=kanan;

$1 / / / / / / / / / / / / / / / / / / / / / / / / / 1$

$1 / / / / / / / / / / / / / / / / 1$

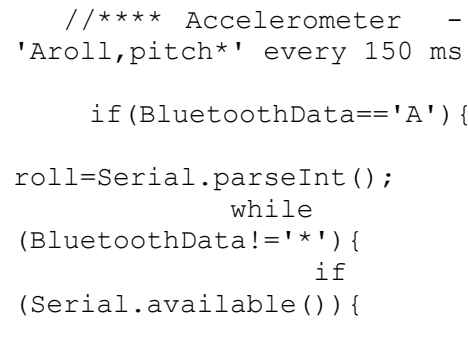

BluetoothData=Serial.read ();

if (BluetoothData==' , ') pitch=Serial -parseInt (); \} \}

if $(\operatorname{acc}$ on $)\{$

$\operatorname{rol} 1<180) \quad$ if $\quad((\operatorname{rol} 1>0 \quad \& \&$

$\quad($ pitch $>0 \quad \& \&$

pitch<180))

servo2.write (servos1);

servo4.write (180

if $((\operatorname{roll}<0))$

if (dua) \{

servo3.write (servos3kanan);

if $\quad((\operatorname{roll}>=0))$

servo3.write (servoS3kiri):

\} \} \}

c. Download Program

Langkah selanjutnya yaitu mendownload program dari komputer ke mikrokontroller. Alat yang digunakan untuk memindahkan program dari komputer ke mikrokontroller yaitu Downloader.

\section{Hasil Pengujian Robot}

Pada tahap pengujian robot ini, robot akan diuji dengan menggunakan smartphone android untuk melakukan pergerakan. dapat dilihat pada gambar 13 .

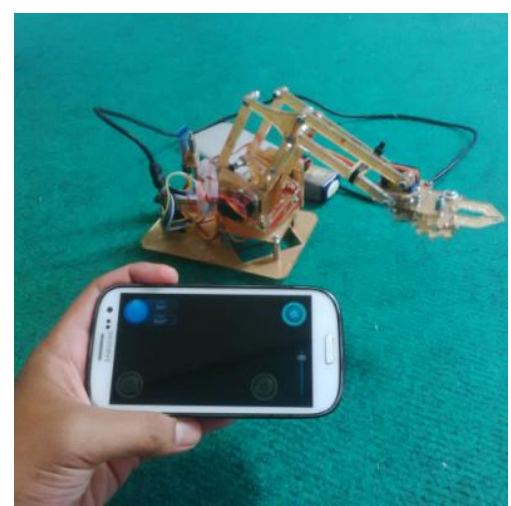

\section{Gambar 13. Pengujian Robot}

Pada pengujian robot ini, ada beberapa aspek yang akan diuji, yaitu:

\section{Aspek Derajat Pergerakan}

Kondisi-kondisi yang diuji pada robot beserta hasil pengujian untuk aspek derajat pergerakan ini dapat dilihat pada tabel 3.1.

Tabel 1. Kondisi Pengujian Robot Pada Aspek Jarak

\begin{tabular}{|c|c|c|}
\hline No & Kondisi & Hasil Pengujian \\
\hline 1 & $\begin{array}{l}\text { Jika derajat } \\
\text { kemiringan } \\
\text { smartphone } \\
\text { lebih dari } 180 \\
\text { derajat, } \\
\text { dapatkah robot } \\
\text { bergerak } \\
\text { sesuai derajat } \\
\text { kemiringan } \\
\text { smarphone? }\end{array}$ & $\begin{array}{l}\text { Robot tidak } \\
\text { bisa bergerak } \\
\text { melebih derajat } \\
\text { kemiringan } 150 \\
\text { derajat, jika } \\
\text { melebihi maka } \\
\text { robot hanya } \\
\text { bergerak } 150 \\
\text { derajat saja. }\end{array}$ \\
\hline 2 & $\begin{array}{lr}\text { Jika derajat } \\
\text { kemiringan } \\
\text { smartphone } \\
\text { lebih dari } 0 \\
\text { derajat dan } \\
\text { kurang dari } \\
180 \text { derajat, } \\
\begin{array}{l}\text { apakah robot } \\
\text { bisa }\end{array}\end{array}$ & $\begin{array}{l}\text { Bisa, karena } \\
\text { logika fuzzy } \\
\text { yang telah di } \\
\text { masukkan } \\
\text { kedalam } \\
\text { program untuk } \\
\text { derajat } \\
\text { kemiringan nya } \\
\text { adalah }\end{array}$ \\
\hline
\end{tabular}




\begin{tabular}{|c|c|c|}
\hline & $\begin{array}{l}\text { menyesuaikan } \\
\text { derajat } \\
\text { kemiringan } \\
\text { smartphone? }\end{array}$ & $\begin{array}{ll}\text { sampai } & 180 \\
\text { derajat. } & \end{array}$ \\
\hline 3 & $\begin{array}{l}\text { Jika derajat } \\
\text { kemiringan } \\
\text { smarphone } \\
\text { berputar dari } 0 \\
\text { hingga } 360 \\
\text { derajat dan } \\
\text { kembali lagi ke } \\
\text { kemiringan } \\
\text { kurang dari } \\
180 \text { derajat, } \\
\text { bagaimana } \\
\text { pergerakan } \\
\text { robot? }\end{array}$ & $\begin{array}{lr}\text { Robot akan } \\
\text { mengambil } \\
\text { data } \\
\text { kemiringan } \\
\text { hinggan } 180 \\
\text { derajat yang } \\
\text { terbaru dari } \\
\text { smartphone } \\
\text { dan } \\
\text { mengabaikan } \\
\text { derajat } \\
\text { kemiringan } \\
\text { lebih dari } 180 \\
\text { derajat. }\end{array}$ \\
\hline
\end{tabular}

Pengujian pergerakan robot berdasarkan derajat kemiringan smartphone dan hasil dari pergerakan robot bisa dilihat pada gambar 14.
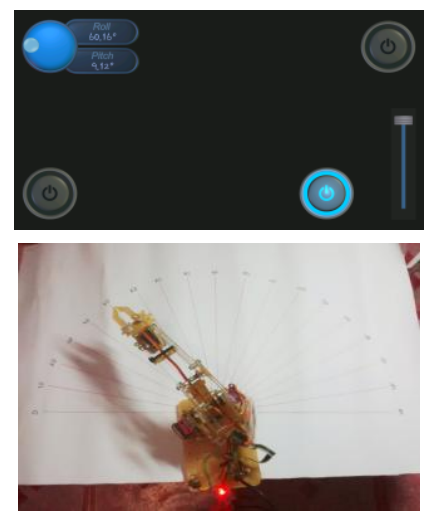

Gambar 14. Pengujian Robot Berdasarkan Derajat Kemiringan Aspek Komunikasi Robot dengan Smartphone

Kondisi-kondisi yang diuji pada robot beserta hasil pengujian untuk aspek komunikasi robot dengan smartphone ini dapat dilihat pada tabel 2.

Tabel 2. Kondisi Pengujian Robot Pada Aspek Perbedaan Ruangan

\begin{tabular}{|c|l|l|}
\hline No & Kondisi & Hasil Pengujian \\
\hline 1 & $\begin{array}{l}\text { Jika } \\
\text { smartphone }\end{array}$ & $\begin{array}{l}\text { Robot tidak bisa } \\
\text { menerima data }\end{array}$ \\
\hline
\end{tabular}

\begin{tabular}{|c|l|l|}
\hline dan robot & $\begin{array}{l}\text { dari smarphone } \\
\text { jika berada } \\
\text { didalam } \\
\text { dalam ruangan } \\
\text { luangan yang } \\
\text { berbeda, } \\
\text { apakah robot } \\
\text { bisa } \\
\text { menerima } \\
\text { karena } \\
\text { data darhalang oleh } \\
\text { smarphone? } \\
\text { dinding dan } \\
\text { menghambat } \\
\text { signal input dari } \\
\text { smarphone. }\end{array}$ \\
\hline 2 & $\begin{array}{l}\text { Jika } \\
\text { Smartphone } \\
\text { yang } \\
\text { digunakan } \\
\text { berbeda- } \\
\text { beda, apakah } \\
\text { bisa robot } \\
\text { membaca } \\
\text { data dari input } \\
\text { dari } \\
\text { smartphone? }\end{array}$ & $\begin{array}{l}\text { Bisa, asalkan } \\
\text { smartphone } \\
\text { yang digunakan } \\
\text { memiliki sensor } \\
\text { accelerometer. }\end{array}$ \\
\hline
\end{tabular}

Pada kondisi komunikasi robot dengan smartphone ada beberapa jenis smartphone yang bisa dan tidak bisa mengontrol robot Arm. Salah satu Smartphone nya bisa dilihat pada gambar 15.

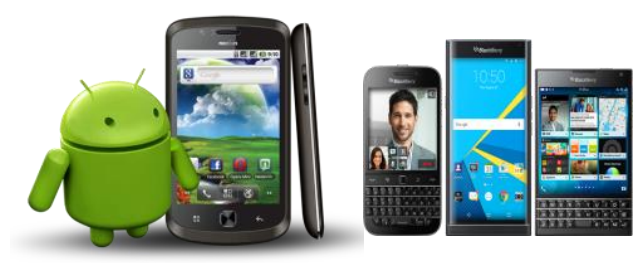

\section{Gambar 15. Smartphone Android dan Smartphone Blackberry}

Pada smartphone jenis Android ini bisa mengakses atau mengontrol robot, karena pada smatphone android itu sendiri memiliki sensor accelerometer yang bisa kita manfaatkan untuk pengontrol robot dan untuk aplikasinya sendiri kita bisa dengan bebas membuat dan menginstallasi aplikasinya ke dalam smartphone. Dan ada juga beberapa smarphone Android versi lama yang tidak memiliki sensor accelerometer, sehingga kita tidak bisa 
menggunakan sebagai pengontrol robot.

Sedangkan pada smartphone jenis blackberry ini tidak bisa mengakses atau mengontrol robot. Karena rata-rata pada smartphone blackberry, tidak memiliki sensor accelerometer untuk kita manfaatkkan pada robot. Dan untuk aplikasinya kita tidak bisa secara bebas membuat atau menginstallasi pada smartphone blackberry. Dan ada juga beberapa jenis smartphone blackberry yang memiliki sensor accelerometer tetapi kita tidak bisa memanfaatkan atau mengakses sensor tersebut karena dari pihak blackberry tidak menyediakan aplikasi yang di install atau dibuat secara bebas.

Beberapa Jenis Smartphone Android yang bisa digunakan dan tidak bisa digunakan berdasarkan spesifikasinya bisa dilihat pada tabel 3.

\section{Tabel 3. Spesifikasi Smartphone}

Yang Bisa Digunakan dan Yang Tidak Bisa Digunakan Pada Robot Arm

\begin{tabular}{|c|c|c|c|c|}
\hline $\begin{array}{l}N \\
0\end{array}$ & $\begin{array}{c}\text { Jenis } \\
\text { Handph } \\
\text { one }\end{array}$ & $\begin{array}{c}\text { Sensor } \\
\text { Accelero } \\
\text { meter }\end{array}$ & $\begin{array}{l}\text { Bluet } \\
\text { ooth }\end{array}$ & $\begin{array}{c}\text { Keter } \\
\text { anga } \\
n\end{array}$ \\
\hline 1 & $\begin{array}{c}\text { Samsu } \\
\text { ng } \\
\text { Galaxy } \\
\text { Mini }\end{array}$ & $\begin{array}{c}\text { Tidak } \\
\text { Ada }\end{array}$ & Ada & $\begin{array}{c}\text { Tidak } \\
\text { Bisa } \\
\text { Digun } \\
\text { akan }\end{array}$ \\
\hline 2 & $\begin{array}{c}\text { Samsu } \\
\text { ng } \\
\text { Galaxy } \\
\text { Tablet }\end{array}$ & Ada & Ada & $\begin{array}{c}\text { Bisa } \\
\text { Digun } \\
\text { akan }\end{array}$ \\
\hline 3 & $\underset{4 \mathrm{i}}{\text { Xiaomi }}$ & Ada & Ada & $\begin{array}{c}\text { Bisa } \\
\text { Digun } \\
\text { akan }\end{array}$ \\
\hline 4 & Mito & $\begin{array}{c}\text { Tidak } \\
\text { Ada }\end{array}$ & Ada & $\begin{array}{c}\text { Tidak } \\
\text { Bisa } \\
\text { Digun } \\
\text { akan }\end{array}$ \\
\hline 5 & $\begin{array}{c}\text { Samsu } \\
\text { ng } \\
\text { Galaxy } \\
\text { SIII }\end{array}$ & Ada & Ada & $\begin{array}{c}\text { Bisa } \\
\text { Digun } \\
\text { akan }\end{array}$ \\
\hline
\end{tabular}

Berdasarkan tabel diatas bisa diambil kesimpulan bahwa untuk mengontrol robot Arm tersebuat harus memiliki spesifikasi smartphone yang memiliki bluetooth dan sensor acceleromete. Agar robot bisa di akses dan dikontrol.

\section{Analisa Pergerakan Robot}

Dapat dilihat pergerakan

robot sebelum menggunakan algoritma Fuzzy pada gambar 16.
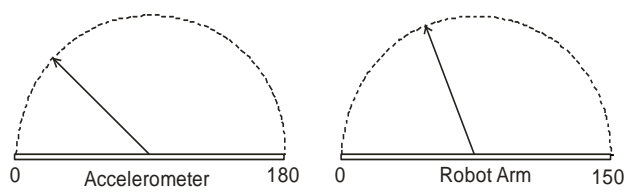

\section{Gambar 16. Pergerakan Robot sebelum menggunakan Fuzzy}

Kemiringan Smartphone dengan Robot belum beraturan, memiliki nilai error tinggi, sering berbeda gerakan. dan setelah Robot menggunakan algoritma Fuzzy, Robot dapat bergerak beraturan mengikuti pergerakan smartphone, dengan meminimalkan nilai error dan mengurangi kesalahan pergerakan, dapat dilihat pada gambar 17.

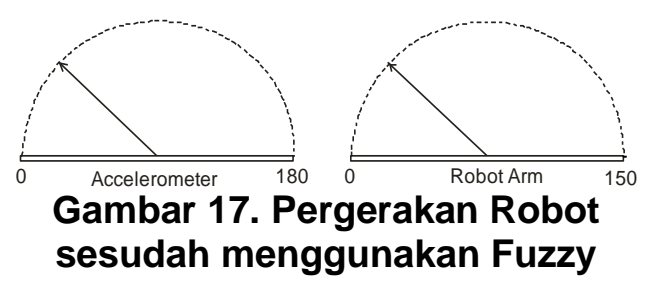

\section{KESIMPULAN}

Berdasarkan hasil pengujian yang telah dilakukan, dapat diambil kesimpulan-kesimpulan, yaitu:
a. Penerapan algoritma Fuzzy Logic pada robot Arm berjalan dengan baik dan sesuai dengan pergerakan accelerometer pada smartphone Android.
b. Ketelitian dalam pembuatan
robot terutama pada perangkat 
robot, penerapan algoritma Fuzzy Logic dengan input kemiringan yang presisi pada robot agar dapat diolah, supaya tidak memiliki error yang besar.

\section{DAFTAR PUSTAKA}

[1] Hong, Tang Sai, Nakhaeinia, Danial dan Karasfi, Babak (2012)," Application of Fuzzy Logic in Mobile Robot Navigation", HIm. 21-35.

[2] Meshram, Ritesh(2013), "Motion Control of Wheeled Mobile Robots Using Fuzzy Logic", International Journal of Recent Technology and Engineering (IJRTE) ISSN: 2277-3878, Volume-2, Issue-3, July 2013.

[3] Rashid, Razif, Elamvazuthi, I, Begam, Arrofiq (2010)," Fuzzybased Navigation and Control of a Non-Holonomic Mobile Robot. ", Journal Of Computing, ISSN 2151-9617, Volume 2, Issue 3, HIm. 130137.

[4] Simon dan Mohan Peri, Vamsi (2013)," Fuzzy Logic Control For An Autonomous Robot".

[5] Fatmi, Anis, Yahmadi, Khriji, and Masmoudi (2008)," A Fuzzy Logic Based Navigation of a Mobile Robot", World Academy of Science, Engineering and Technology 222008.

[6] Wiria Nugraha, Deny (2010), Perancangan Sistem Kontrol Robot Lengan Yang Dihubungkan Dengan Komputer.

[7] Suyanto (2014),"Artificial Intelligence - Searching,
Reasoning, Planing dan Learning", Revisi Kedua.

[8] Triwiyatno, Aris (2011), "Buku Ajar Sistem Kontrol Analog.", HIm. 1-11. $<$ URL:http://aristriwiyatno.blog. undip.ac.id/files/2011/10/Bab1 Konsep-Umum-SistemKontrol.pdf>. diakses pada 22 Mei 2016.

[9] Naba, Agus, Dr. Eng (2009) “ Belajar Cepat Fuzzy Logic Menggunakan MATLAB". Yogyakarta: Andi.

[10] R.Annamaria, Várkonyi-Kóczy (2010)," A Complexity Reduced Hybrid Autonomous Navigation Method for In-Door Robots

[11] Pitowarno, Endra (2006), "Robotika: Desain, Kontrol, dan Kecerdasan Buatan". Yogyakarta: Andi.

[12] Kusumadewi, Sri, dan Purnomo, Hari (2010), Aplikasi Logika Fuzzy Untuk Pendukung keputusan Edisi 2". Yogyakarta: Graha IImu.

[13] Suksmadana, Budi (2011), "Rancang Bangun Robot Mobil Menggunakan Logika Fuzzy Untuk Bernavigasi Berbasiskan Mikrokontroller AVR ATMega8535"

[14] Awal, Hasri (2016), " Algoritma Fuzzy Logic Dan Wallfollower Pada Sistem Navigasi Robot Hexapod Mikrokontroller AVR"

[15] Caysar, Dina (2014), Pengaturan Pergerakan Robot Lengan Smart Arm Robotic $A x-12 A$ Melalui Pendekatan Geometry Based Kinematic Menggunakan Arduino. 
[16] Hermanto, Dedy (2015), "Pengontrolan Gerak Mobile Robot Menggunakan Sensor Accelerometer Pada Perangkat Bergerak Android.", CSRID Journal, Vol.7 No.1 Februari 2015, Hal. 1-11

[17] Rezoug and Hamerlain (2009), " Fuzzy Logic Control for Manipulator Robot actuated by Pneumatic Artificial Muscles.", Journal of electrical systems, Special Issue $\mathrm{N}^{\circ}$ 01. HIm. 1-6.

[18] Sutojo, T, Mulyanto, Edi, Suhartono, Vincent, Dr. (2011),"Kecerdasan Buatan".

[19] Kusumadewi, Sri, Hartati, Sri (2010), "Neuro-Fuzzy Integrasi Sistem Fuzzy \& Jaringan SYaraf", Edisi 2.

[20] Kusumadewi, Sri (2003), "Artificial Intelligence (Teknik dan aplikasinya)". Yogyakarta: Graha IImu. 